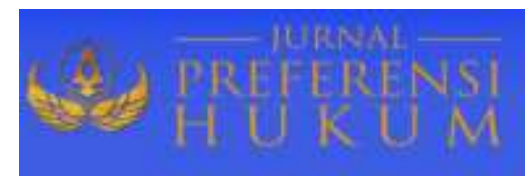

Jurnal Preferensi Hukum | ISSN: 2746-5039

Vol. 2, No. 2 - Juli 2021, Hal. 371-376| Available online at https://www.ejournal.warmadewa.ac.id/index.php/juprehum

DOI: https://doi.org/10.22225/jph.2.2.3340.371-376

\title{
PERLINDUNGAN HUKUM ATAS HAK KEKAYAAN INTELEKTUAL KARYA SENI MUSIK GAMELAN BALI
}

\author{
Anak Agung Ayu Gayatri, Anak Agung Sagung Laksmi Dewi, Luh Putu Suryani \\ Fakultas Hukum, Universitas Warmadewa, Denpasar-Bali, Indonesia \\ gungayugayatril7@gmail.com, laksmiidewi29@gmail.com, putusurvani099@gmail.com
}

\begin{abstract}
Abstrak
Indonesia memiliki beragam seni tradisional salah satunya karya seni musik gamelan Bali, seiring berkembangnya jaman begitu juga teknologi dan internet maka sebuah karya seni musik gamelan Bali mudah untuk dinikmati oleh masyarakat tetapi rentan terjadi pelanggaran hak cipta. Gamelan Bali adalah alat musik tradisional khas Bali yang memiliki bunyi yang unik lalu dikembangkan dan dilestarikan oleh para seniman Bali demi mengantisipasi terjadinya sengkera, dan mendapatkan kepastian hukum bagi pencipta karya seni musik gamelan Bali dalam berkarya. Tujuan dari penelitian ini guna mengetahui pengaturan hukum terhadap hak kekayaan intelektual karya seni musik gamelan Bali dan mengetahui perlindungan hukum atas hak kekayaan intelektual karya seni musik gamelan Bali. Dengan menggunakan metode penelitian normatif. Hak Kekayaan Intelektual terdiri dari hak cipta yang diatur dalarn Undang-Undang no.28 tahun 2014 tentang Hak Cipta yang mengatur tentang ciptaan yang dilindungi, ekspresi budaya tradisional, serta upaya penegakan hukum melalui gugatan perdata, tuntutan pidana, arbitrase dan upaya hukum dan sanksi pidana. Sebaiknya Undang-Undang Hak Cipta mengatur mengenai karya seni musik tradisional dengan lebih rinci dan dikembangkan dengan menelaah pelanggaran hukum yang terjadi melalui kecanggihan teknologi baik dalam negeri maupun luar negeri.
\end{abstract}

Kata Kunci: Hak Cipta, Gamelan Bali, Karya Seni Musik, Perlindungan Hukum.

\begin{abstract}
Abstrak
Indonesia has a variety of traditional arts, one of which is Balinese gamelan music, along with the development of times as well as technology and the internet, a Balinese gamelan music art is easy for the public to enjoy but is prone to copyright infringement. The Balinese gamelan is a traditional Balinese musical instrument that has a unique sound which is then developed and preserved by Balinese artists in anticipation of the occurrence of sengkera, and to obtain legal certainty for creators of Balinese gamelan music in their work. The purpose of this study is to determine the legal arrangements for the intellectual property rights of Balinese gamelan music and to know the legal protection of intellectual property rights of Balinese gamelan music. By using normative research methods. Intellectual Property Rights consist of copyrights regulated in Law No.28 of 2014 concerning Copyright which regulates protected works, traditional cultural expressions, and law enforcement efforts through civil suits, criminal charges, arbitration and legal remedies and criminal sanctions. It is better if the Copyright Law regulates traditional music works of art in more detail and is developed by examining legal violations that occur through technological sophistication both domestically and abroad.
\end{abstract}

Keywords: Copyright, Balinese Gamelan Music Artwork, Legal Protection.

\section{PENDAHULUAN}

Indonesia memiliki beragam seni dan budaya tradisional di setiap daerahnya, salah satunya karya seni musik tradisional yang berasal dari Bali yaitu karya seni musik gamelan Bali yang memiliki bunyi khas dan unik. Di setiap daerahnya merniliki ragam seni dan budaya yang berbeda-beda maka tak heran walau kini adalah era globalisasi yang serba modern lndonesia tetap terasa kental akan budayanya. Namun menyadari seiring kemajuan zaman dan teknologi masyarakat yang sadar bahwa kekayaan budaya tradisional ini adalah aset yang berharga dari segi ekonomi bagi bangsa maka dari itu masyarakat harus tahu tentang pengetahuan tradisional atau yang dikenal dengan Traditional knowledge dan Ekspresi Budaya Tradisional.

Perlindungan hukum adalah memberikan pengayoman terhadap hak asasi manusia (HAM) yang dirugikan orang lain dan perlindungan itu diberikan kepada masyarakat agar dapat menikmati semua hak-hak yang diberikan oleh hukum (Satjipto Rahardjo; 2000; 69). Sedangkan menurut Philipus M.Hadjon bahwa perlindungan hukum bagi rakyat sebagai tindakan pemerintah yang bersifat preventif 
dan represif. Perlindungan hukum yang preventif bertujuan untuk mencegah terjadinya sengketa, yang mengarahkan tindakan pemerintah bersikap hati - hati dalam pengambilan keputusan berdasarkan diskresi dan perlindungan yang represif bertujuan untuk mencegah terjadinya sengketa melalui lembaga peradilan (Satjipto Rahardjo; 2000; 54). Menurut Rasjidi dan I.B Wyasa Putra bahwa hukum dapat difungsikan untuk mewujudkan perlindungan yang sifatnya tidak sekedar adaptif dan fleksibel melainkanpredektif dan antipatif (Lili Rasjidi, dan I.B Wyasa Putra; 1993; 118).

Hak Kekayaan Intelektual biasanya disingkat seperti HKI, yaitu dalam bahasa inggris disebut dengan Intellectual PropertyRights, yaitu hak yang timbul bagi hasil olah pikir yang menghasilkan suatu produk atau proses yang berguna untuk manusia. Yang pada dasarnya HKI itu hak yang berguna secara ekonomis hasil dari sebuah kreativitas, gagasan intelektual. Objek yang diatur dalam HKI yaitu sebuah karya - karya yang nyata dan timbul atau lahir akibat kemampuan intelektual manusia. Perlindungan Hukum pada HKI merupakan hak yang diperoleh oleh undang-undang, dan barang siapa yang melanggamya maka bisa diberikan sanksi. Perlindungan hukum tersebut berguna untuk upaya penegakan yang diatur oleh undang-undang untuk mengantisipasi terjadinya pelanggaran HKI termasuk juga Hak Cipta oleh orang lain.

Kekayaan Intelektual merupakan kreatifitas yang dihasilkan dari oleh manusia dalam rangka memenuhi kebutuhan dan kesejahteraan hidup manusia. Kreatifitas manusia tersebut dapat terjadi pada bidang-bidang ilmu pengetahuan, seni, sastra, tekhnologi, bisnis. Pada akhirnya diperlukan pengakuan dan juga penghargaan (reward) terhadap hasil kreatifitas seseorang dengan tatanan hukum yang disebut rejim hukum hak kekayaan intelektual. Rejim hukum ini memberikan perlindungan terhadap hasil karya penemu (inventor) atau pencipta dari pihak lain yang secara tidak sah menggunakan ataupun memanfaatkan hasil karyannya (Amalia Resti Faozi 2018).

Mengenai Hukum pada HKI merupakan hak ekonomis yang berguna untuk pencipta yang diberikan oleh hukum atau peraturan karena suatu karya hasil dari kemampuan intelektual seseorang. Karya seni musik gamelan Bali merupakan karya cipta tradisional dari hasil ide, kreatifitas yang berasal dari intelektual seseorang dikembangkan atau dilestarikan seiring perkembangan zarnan oleh para senirnan dan musisi Bali. Dengan kemajuan teknologi, informasi melalui internet maka semakin mudah untuk dinikmati oleh rnasyarakat mengingat bahwa karya seni musik gamelan Bali kini banyak dikagumi masyarakat dan wisatawan mancanegara. Karya seni ini masuk dalam rezim Hak cipta yang diarur dalam Undang - undang Hak Cipta NO. 28 tahun 2014. Menyadari kini semakin mudah terjadi pelanggaran Hak Cipta, sengketa dan perselisihan maka diperlukannya perlindungan hukum atas suatu karya seni musik gamelan Bali.

Beberapa penelitian serupa yang dijadikan penulis sebagai acuan penyusunan penulisan penelitian ini yakni penelitian yang dilakukan oleh Ni Wayan Masyuni Sujayanthi dan Agus Ngurah Arya Putraka "Perlindungan Hukum Terhadap Alat Musik Tradisional Bali". Kholis Roisah "Perlindungan Ekspresi Budaya Tradisional Dalam Sistem Hukum Kekayaan Intelektual". Amalia Resti Faozi "Perlindungan Hukum Terhadap Karya Cipta Ekspresi Budaya Tradisional di Bidang Seni Tari" Universitas Muhammadiyah Surakarta.

Tujuan dari penelitian ini untuk mengetahui pengaturan hukum terhadap Hak Kekayaan Intelektual karya seni musik gamelan Bali dan untuk merlindungan hukum atas Hak Kekayaan Intelektual Karya seni musik gamelan Bali.

\section{METODE PENELITIAN}

Jenis penelitian yang digunakan adalah jenis penelitian hukum normatif. Mengenai sumber bahan hukum yang digunakan terbagi atas bahan hukum utama yang merupakan bahan hukum utama dan menjadi dasar penelitian tesis ini. Bahan Hukum sekunder adalah adalah bahan hukum yang digunakan untuk menunjang atau membantu dalam memberikan pemahaman-pemahaman dan gambarangambaran serta teori-teori hukum yang digunakan untuk mengulas dan memecahkan persoalanpersoalan yang akan di teliti di dalam penelitian penulisan proposal skripsi. Untuk memperoleh bahan hukum primer, sekunder, dan tersier, maka teknik penghitungan atau penelusuran bahan hukum dalam daftar tersebut dikelompokkan, dan digunakan metode kualitatif mencatat, rnencatat, mengutip, meringkas, dan meninjau sesuai kebutuhan. Setelah mengumpulkan bahan hukum tingkat pertama dan kedua, maka akan menggunakan rnetode pengolahan bahan hukum yang sistematis untuk pengolahan dan analisisnya. 


\section{HASIL DAN PEMBAHASAN}

\section{Pengaturan Hukum Atas Hak Kekayaan Intelektual Karya Seni Musik Gamelan Bali}

Secara normatif, Hak Kekayaan Intelektual yaitu product of mind atau World IntellectualProperty Organisation (WIPO), creation of mind yang artinya suatu buah karya manusia yang lahir melalui curahan pikiran, tenaga, rasa dan karsa, cipta, waktu, dan biaya (Adrian Sutedi, 2009 38). Dengan melihat pengertian dari HKI sudah menjadi sesuatu yang wajar jika para penikmat atau pengguna hasil kreativitas seseorang memberikan penghargaan kepada orang yang memiliki kreativitas tersebut (Dian Purnamasari, 2013 150).

Dasar hukum yang mencakup Karya seni musik gamelan Bali masuk dalam rezim Hak Cipta yaitu UUHC No.28 Tahun 2014 dalam pasal I ayat (I) mengenai pengertian Hak Cipta, Hak Cipta merupakan cakupan dari sekelompok hak yang disebut dengan (HKI) atau Hak Kekayaan Inrelekrual yang aturannya daiam ilmu hukum disebut juga sebagai hukum HK.I, tentunya begitu yang meliputi hak-hak yuridis dan karya cipta atau hasil ciptaan dari pemikiran manusia yang berkesinambungan dengan kepentingan yang berupa ekonomi dan moral.

Pada UUHC juga mengatur tentang Hak Moral karya cipta pada pasal 5 UUHC dan pasal 8 dan 9 UUHC mengenai Hak Ekonorni pencipta. Mengenai Ekspresi Budaya Tradisional yang mencakup Ciptaan yang apa saja yang dilindungi diatur dalarn pasal 40 UUHC. Dan yang disebut dengan ekspresi budaya tradisional tergolong salah satu atau gabungan dan kombinasi wujud ekspresi sebagai berikut pada kejelasan pasal 38 (1). Ciptaan memiliki wujud yang khas serta menunjukkan keaslian sebagai dasar kemampuan kreativitas pribadi karena ciptaan adalah ego tertinggi atau alter ego (Damian, Eddy, 2003 123).

Dengan dernikian seni musik gamelan Bali tidak pemah mati dan turut berkembang terutama pada kreativitas penerus generasi muda di Bali yang merniliki banyak ide untuk mengembangkan seni musik gamelan Bali seperti karya seni musik gamelan Bali kontemporer yang tentunya banyak dikagumi masyarakat lokal maupun wisatawan mancanegara. Seperti musisi asal Bali yang bemama Agus Teja sentosa atau yang dikenal dengan Gus Teja seorang maestro alat musik tradisional suling dengan karya seni musiknya yang berjudul Hero banyak dikagumi oleh masyarakat dan mancanegara yang sudah dikenal melalui konsemya keluar negeri.

Dalam UUHC mengatur mengenai pencatatan Hak cipta, tata cara pencatatan yang disesuaikan dengan pasal 66 UUHC No. 28 tahun 2014. Tujuan dari pencatatan suatu ciptaan terutama karya seni musik gamelan Bali adalah untuk mengantisipasi terjadinya perselisihan, sengketa dan kepastian hukum bagi suatu karya seni musik gamelan Bali dan kenyamanan para seniman dan musisi Bali dalarn mengembangkan karya seni musik gamelan Bali. Seni gamelan Bali teren hidup ditengah masyarakat, menjadi bagian tak terpisahkan di rnasyarakat Bali (I Made Bandem, 2013 21).

Hal ini dikarenakan sifat gamelan Bali yang terbuka terhadap pembaruan sama halnya dengan masyarakat Bali yang terbuka pada masyarakat luar, dengan begiru karya seni musik gamelan Bali sangat dikenal dan dikagumi oleh masyarakat lokal maupun wisatawan luar, tidak hanya dikenal dan dikagumi tetapi warga asing yang berasal dari luar negerijuga ingin belajar cara memainkannya. Maka beberapa seniman Bali mengembangkan gamelan Bali dengan ranah yang semakin inovatif kontemporer atau modern.

\section{Perlindungan Hukum Atas Hak Kekayaan Intelektual Karya Seni Musik Gamelan Bali}

Pelanggaran Hak Cipta menurut UUHC No.28 tahun 2014 mengenai Hak Cipta pada umumnya ada dua yaitu pelanggaram terhadap hak moral dan hak ekonomi pencipta. Pelanggaran terhadap hak moral diarur pada pasal 98, dan bisa ditandakan dengan gugatan perdata serta ganti rugi melalui pengadilan niaga. Lembaga yang dibolehkan berwenang atas menyelesaikan suaru perkara perdata pelanggaran terhadap hak ekonomi yaitu pengadilan niaga pelanggaran atas hak ekonorni diatur dalam pasal 96 UUHC.

Dalam pelanggaran karya seni musik gamelan Bali rentan diambil atau diakui oleh masyarakat lokal, baik luar Bali maupun mancanegara, dan dipergunakan tanpa seizin pencipta baik dari segi moral tanpa mencantumkan judul dan nama pencipta dan merugikan dalam segi ekonomi untuk keperluan komersial individu atau pihak luar Bali bahkan mancanegara tanpa bayar royalti atau keuntungan yang seharusnya diterima oleh pemegang hak cipra. Begitulah penyebab jika suatu karya cipta seni musik gamelan Bali perlu dilindungi dalam payung hukum, karena musik gamelan Bali rnerupakan seni komersial bagi penciptanya selain itu Bali adalah pulau yang sangat dikenal oleh masyarakat luar negeri 
adat istiadat, budaya tradisionalnya, selain tarian juga salah satunya gamelan Bali yang sangat dikagumi oleh mereka para masyarakat lokal, indonesia dan luar negeri.

Dalam perlindungan hukum represif dengan berdasarkan Undang-undang No. 28 tahun 2014 mengenai Hak cipta dalam upaya penegakan hukum atas suatu sengketa yang diatur dalam pasal 95 . Suatu tindakan bisa dianggap sebagai pelanggaran hak cipta apabila perbuatan tersebut mengarah pada pelanggaran hak eksklusif yang dimiliki oleh pencipta atau pemegang hak cipta. Dalam peraturan UUHC pelanggaran Hak Cipta bisa diselesaikan melalui tiga cara dengan sebagai berikut, melalui pengadilan atau litigasi, arbitrase, atau alternatif penyelesaian sengketa. Pengadilan yang atau diperbolehkan berwenang untuk mengadili atau menyelesaikan sengketa hak cipta adalah Pengadilan Niaga.

Apabila ada pihak yang hendak melakukan penuntutan secara pidana harus ditempuh upaya penyelesaian melalui jalur mediasi terlebih dahulu pasal 95 ayat (4). Penyelesaian kasus melalui alternatif dalam model negosiasi, mediasi, konsiliasi. Tahap Gugatan juga diatur dalam pasal 100 UUHC No. 28 tahun 2014. Mediasi yaitu upaya hukum untuk penyelesaian kasus atau perselisihan dengan keterlibatan para pihak ketiga netral, dan tidak mempunyai kewenangan unruk menyimpulkan suatu keputusan guna membantu para pihak yang memiliki perselisihan dengan mencapai hasil akhir yang diterima oleh para pihak. Dengan Berdasarkan hak cipta 96 ayat (1) yang berhak mendapatkan ganti rugi.

Secara teoritis, kata ganti rugi merujuk pada suatu peristiwa atau kejadian yang menunjukkan ada pihak yang menderita kerugian, da nada pihak yang diberikan kewajiban untuk mengganti suatu kerugian yang dialami oleh pihak lain karena perbuatannya. Pembaca putusan itu diharuskan diucapkan pada sidang terbuka untuk umum sesuai dengan aturan dalam UU kekuasaan keHKIman. Putusan pengadilan niaga sehabis dibacakan pada sidang terbuka secara umum, harus disampaikan oleh juru sita kepada para pihak paling lambat empat belas hari terhitung sejak putusan dibacakan (Harjono, dkk. 2019:75)

Menyadari hak moral dari pencipta karya seni musik gamelan Bali sangat pentingjuga bagi pencipta karena salah satu seniman Bali yang bernama Gus Teja mengalami kerugian dalam hak moralnya sebagai pencipta yaitu karya musiknya kedapatan dipergunakan oleh brand atau merek tas ternama di dunia tanpa seizin Gus Teja dan tanpa mencantumkan nama penciptanya dalam pemakaian musiknya tersebut yang berjudul Hero. Di negara hukurn seperti Indonesia menyadari hasil ciptaan umumnya mulai dijual ke pasar dalam negeri dan mancanegara agar mendapatkan keuntungan secara ekonomis untuk semua pencipta dan yang berhak atas suatu ciptaan untuk dapat dinikmati bagi masyarakat luas. Mengingat bahwa banyak terjadi pelanggaran Hak cipta dalam suaru karya cipta salah satunya karya seni musik yang merugikan para pencipta baik dalam hak moral dan hak ekonomi yang dimilikinya, terutama dalam karya seni musik dari alat musik tradisional khususnya gamelan Bali yang kini banyak dikembangkan oleh para seniman Bali baik dari generasi muda yang bisa dinikmati melalui situs internet tidak hanya masyarakat lokal Bali, seluruh Indonesia dan mancanegara dapat menikrnatinya.

Maka dalam hal ini pihak yang dirugikan adlah pencipta, yang berwenang atas suatu ciptaan, sedangkan pihak yang dibebankan kewajiban adalah pelanggar hak cipta. Peraturan pada pasal 96 UUHC, Dalam pasal 96 ayat (2) dan (3) telah ditetapkan bahwa ganti rugi diberi dan dicantumkan sekaligus dalam bentuk putusan pengadilan mengenai perkara pidana hak cipta atau hak terkait. Menanggung ganti rugi tersebut kepada pencipta, pemegang hak cipta dan pemilik hak terkait dibayarkan paling lama yaitu 6 bulan sehabis putusan itu dengan kekuatan hukum tetap. Pengalihan pada hak cipta terhadap semua ciptaan dengan orang lain tidak menghilangkan hak pencipta untuk menggugat setiap orang yang dengan sengaja dan tanpa haknya dengan tanpa persetujuan pencipta yang melakukan pelaanggaran hak moral pencipta. Hak moral pencipta adalah hak yang melekat secara abadi pada diri pencipta yang sudah dijelaskan melalu peraturan UUHC pasal 5 ayat (1).

Menyadari hal itu, arti penting suaru karya cipta seni musik gamelan Bali untuk dilindungi dari para pihak yang tidak bertanggung jawab maka para seniman atau musisi Bali untuk segera mendaftarkan karya cipta seni musik gamelan Bali agar dapat mendapatkan perlindungan hukum baik dalam hak ekonomi dan hak moral yang dimiliki oleh pencipta. Bagaimanapun pencipta karya seni musik gamelan Bali telah mewujudkan dalam bentuk nyata pemikiran, ide, kreatifitasnya. Mengingat bahwa gamelan Bali merupakan alat musik tradisional yang sepatutnya dijaga, dilindungi serta 
dilestarikan oleh para seniman generasi berikutnya. Karena gamelan Bali memiliki suara yang khas dan seni yang banyak dikagumi masyarakat lokal maupun intemasional.

Pelanggaran karya seni musik gamelan Bali yang merugikan pencipta dalam penggunaannya secara komersial merupakan tindak pidana yang dapat diruntut melalui jalur hukum pidana, peraturan dan sanksi terhadap pelanggar dapat dilihat dalam pasal 113-120 UUHC mengenai ketentuan pidana sesuai putusan penyelesaian dari pengadilan niaga. Dengan berdasarkan UUHC no 28 tahun 2014 dapat diketahui mengenai penegakan hukum dalam penyelesaian pelanggaran Hak cipta.

\section{SIMPULAN DAN SARAN}

\section{Simpulan}

Dari paparan hasil penelitian dapat disimpulkan bahwa:

1. Aturan Hukum mengenai Hak Kekayaan Intelektual Karya Seni Musik Gamelan Bali diatur dalam Undang-Undang nomor 28th 2014 mengenai Hak Cipta. Dalam peraturan tersebut mengarur mengenai Hak Eksklusif pencipta dari karya seni musik gamelan Bali, serta Hak Moral juga Hak Ekonomi pencipta pada pasal 5 dan pasal 8 Undang Undang Hak Cipta. Serta peraruran mengenai tata cara pencatatan Hak Cipta dengan pasal 66 UUHC NO. 28 tahun 2014 yang berfungsi unruk mengantisipasi terjadinya perselisihan atau sengketa dan kepastian Hukum atas suaru karya seni musik gamelan Bali dan penciptanya.

2. Perlindungan Hukum atas Hak Kekayaan Intelektual Karya Seni Musik Gamelan Bali, dalam perlindungan represif dalam penegakan hukum terhadap suatu pelanggaran Hak cipta dalam penyelesaian sengketa yang diatur dalam pasal 95 UUHC bisa melalui gugatan perdata, tuntutan pidana pada pasal 112-118 UUHC dengan upaya hukum dengan berlakunya sesuai Undang - Undang Hak Cipta No. 28 Tahun 2014 dengan langkah gugatan yang ada dalam pasal 100 UUHC.

\section{Saran}

Berdasarkan hasil penelitian, peneliti memberikan beberapa saran, sebagai berikut:

1. Sebaiknya peraturan perundang-undangan mengenai hak cipta dikembangkan dengan menelaah pelanggaran hak cipta karya seni musik tradisional Bali yang telah terjadi pada perkembangan teknologi, informasi melalui internet yang kini rentan untuk diklaim, disalahgunakan tanpa seizin pencipta dengan memberikan upaya penyelesaian suatu kasus apabila suatu karya cipta tersebut dilanggar oleh masyarakat lokal maupun mancanegara.

2. Para penegak hukum melakukan penindakan terhadap pelanggaran hak cipta atas karya seni musik gamelan Bali lebih giat agar dapat mengurangi kejahatan melalui internet sesuai dengan perkembangan zaman saat ini. Dan memberikan tindakan yang nyata dalam perlindungan karya seni musik baik dalam perlindungan preventif dan represif dengan tetap rnenjatuhkan hukuman yang sesuai dengan peraturan UUHC no. 28 tahun 2014.

3. Diharapkan kepada musisi atau seniman Bali untuk tetap melestarikan seni musik gamelan Bali dengan cara berperan aktif dalam melindungi karya ciptaannya dengan mendaftarkan hasil karya seni musik gamelan yang telah ada sejak dulu unruk dipertahankan agar memperoleh kepastian hukum dan mengantisipasi terjadinya suatu pelanggaran Hak Cipta.

\section{DAFTAR PUSTAKA}

Bandem, I. M. (2013). Gamelan Bali di atas Panggung Sejarah. BP Stikom Bali. Denpasar. Damian, \& Eddy. (2013). Hukum Hak Cipta. Alumni Bandung.

Faozi, A. R. (2018). Perlindungan Hukum Terhadap Karya Cipta Ekspresi Budaya Tradisional Di Bidang Seni Tari. Skripsi. Universitas Muhammadiyah Surakarta. 2018.

Harjono, \& Dkk. (2019). Hukum Acara Penyelesaian Kekayaan Intelektual. Setara Press. Malang.

Kholis Roisah. (2014). Perlindungan Ekspresi Budaya Tradisional Dalam Sistem Hukum Kekayaan Intelektual. Masalah-Masalah Hukum, Vol 43(3).

Ni Wayan Masyuni Sujayanthi, \& Putraka, A. N. A. (n.d.). Perlindungan Hukum Terhadap Alat Musik Tradisional Bali. Kalangwan, Vol 4(2).

Purnamasari, D., \& Dkk. (2010). Hukum Dagang Edisi Revisi. Skripsi. Universitas Trisakti. Jakarta. 
Rasjidi, Lili, \& Putra, I. W. (1993). Hukum Sebagai Suatu Sistem. Remaja Rusdakarya. Bandung

Sutedi, A. (2009). Hak Alas Kekayaan Intelektual. Sinar Grafika. Jakarta.

Sajipto, R. (2000). Ilmu Hukum. PT. Citra Aditya Bakti. Bandung. 